\title{
HUBUNGAN ANTARA POWER OTOT TUNGKAI, KELENTUKAN, DAN PERSEPSI KINESTETIK DENGAN KETEPATAN SHOOTING SEPAKBOLA PADA PEMAIN USIA 12-14 TAHUN SSB MATRA KEBAKKRAMAT KARANGANYAR TAHUN 2020
}

\section{Oleh Feri Fitriyanto}

\begin{abstract}
ABSTRAK
Tujuan dari penelitian ini adalah untuk mengetahui: (1) Hubungan antara power otot tungkai dengan ketepatan shooting pada pemain usia 12-14 tahun SSB Mantra Kebakkramat Karanganyar, (2) Hubungan antara kelentukan dengan ketepatan shooting pada pemain usia 12-14 tahun SSB Mantra Kebakkramat Karanganyar, (3) Hubungan antara persepsi kinestetik dengan ketepatan shooting pada pemain usia 12-14 tahun SSB Mantra Kebakkramat Karanganyar, dan (4) Hubungan antara power otot tungkai, kelentukan, dan persepsi kinestetik dengan ketepatan shooting pada pemain usia 12-14 tahun SSB Mantra Kebakkramat Karanganyar.

Teknik pengumpulan data dalam penelitian ini adalah menggunakan teknik tes dan pengukuran. Adapun jenis tes yang digunakan adalah: (1) Tes Standing broad jump atau untuk mengukur kekuatan otot tungkai, (2) Tes Shuttle run untuk mengukur kelentukan, (3) Tes Soccer Wall Volley untuk mengukur koordinasi mala kaki, dan (4) Tes keterampilan shooting sepakbola.

Berdasarkan analisis data dan pengujian hipotesis yang telah dilakukan, maka simpulan yang dapat diperoleh adalah: (1) Ada hubungan yang positif dan signifikan antara power otot tungkai dengan ketepatan shooting sepak bola pada pemain usia 12-14 tahun SSB Matra Kebakkramat, Karanganyar Tahun 2020, dengan $\mathrm{r} x y=0,458>\mathrm{r} \mathrm{t} 5 \%=0,361$; (2) Ada hubungan yang positif dan signifikan antara kelentukan dengan ketepatan shooting sepak bola pada pemain usia 12-14 tahun SSB Matra Kebakkramat, Karanganyar Tahun 2020, dengan r xy $=0,582>\mathrm{r} \mathrm{t5} \%=0,361$; (3) Ada hubungan yang positif dan signifikan antara persepsi kinestetik dengan ketepatan shooting sepak bola pada pemain usia 12-14 tahun SSB Matra Kebakkramat, Karanganyar Tahun 2020, dengan r xy = 0,450 > $\mathrm{r} \mathrm{t} 5 \%=0,361$; dan (4) Ada hubungan yang positif dan signifikan antara power otot tungkai, kelentukan, dan persepsi kinestetik dengan ketepatan shooting sepak bola pada pemain usia 12-14 tahun SSB Matra Kebakkramat, Karanganyar Tahun 2020 , dengan $\mathrm{Ry}(1,2,3)=0,372>\mathrm{r} \mathrm{t} 5 \%=0,361$ dan $\mathrm{F}$ hitung $=3,394>\mathrm{Ft} 5 \%=$ 2,89 .
\end{abstract}

Kata Kunci: Power Otot Tungkai, Kelentukan, Dan Persepsi Kinestetik, Sepakbola 


\section{A. PENDAhULUAN}

Permainan sepak bola adalah olahraga yang "digandrungi" masyarakat dunia. Di benua Eropa, sepak bola merupakan olahraga yang dikemas sedemikian rupa sehingga bisa mendatangkan uang yang luar biasa banyaknya, di benua Amerika (Latin) masyarakatnya terutama Brazil dan Argentina sepakbola merupakan olahraga favorit, di benua Afrika sepakbola merupakan olahraga yang diharapkan oleh masyarakatnya sebagai mata pencaharian yang dapat menaikkan harkat martabat mereka, di benua Australia olahraga ini semakin populer terlebih ketika tim negara tersebut berhasil masuk putaran dunia, dan benua Asia sepak bola juga merupakan olahraga favorit yang banyak dimainkan masyarakatnya.

Hampir di seluruh pelosok ncgcri sepak bola dimainkan dan menjadi tontonan yang sepertinya tiada habisnya karena hampir setiap hari sepakbola dimainkan oleh masyarakat dan ditonton di televisi. Masyarakat rela "begadangan" untuk melihat permainan sepak bola, apalagi yang bertanding timtim favorit mereka seperti Manchester United, Inter Milan, Real Madrid, Liverpool, dan sebagainya. Itulah fenomena yang tcrjadi di Indonesia, sepak bola menduduki peringkat pertama untuk cabang olahraga yang disukai masyarakat walaupun kalau dicermati masyarakat kita di dalam memainkan sepak bola banyak yang bertujuan untuk sekadar menjaga kebugaran, mengisi waktu luang, cari keringat dan sebagainya yang belum kelihatan untuk tujuan prestasi. Sehingga dalam permainan tersebut tidak terlihat teknik-teknik bermain sepak bola yang terorganisir dengan baik, jadi bisa dikatakan hanya kegiatan "bermain-main" dengan bola yang dilakukan bersama-sama.

Di Karanganyar khususnya Kecamatan Kebakkramat, masyarakatnya juga menyukai sepak bola seperti masyarakat lain di negeri ini, terbukti hampir di lahan-Iahan yang kosong dan sedikit luas dimanfaatkan untuk bermain sepak bola. Tidak jarang di halaman rumah bahkan di dalam rumah pun, anak-anak suka bermain sepak bola. 
Di SSB Matra Kebakkramat Karanganyar khususnya siswa putra usia 12-14 tahun mendapatkan pelajaran sepak bola dan mereka telah diberi materi perlakuan untuk penelitian eksperimen selama kurang lebih dua bulan dengan 3 kali perlakuan/latihan sebagai upaya untuk meningkatkan kemampuan shooting atau menendang bola.

Sehingga dapat dikatakan, siswa putra usia 12-14 tahun tersebut yang terpilih menjadi sample penelitian, sudah dapat melakukan keterampilan teknik sepak bola salah satunya adalah teknik shooting atau dengan kata lain teknik shooting sudah dapat dikuasai dengan baik. Hal inilah yang kemudian membuat peneliti tertarik untuk mengadakan penelitian yakni jenis penelitian korelasional. Maksudnya adalah peneliti tertarik mengadakan penelitian mengenai teknik shooting yang telah dikuasai oleh para siswa putra usia 12-14 tahuan tersebut dengan menghubungkan unsur-unsur kondisi flsik yang mendukung didalam proses pelaksanaan teknik keterampilan gerakan shooting.

Teknik keterampilan dalam permainan sepak bola meliputi: dribbling, shooting, passing, heading, tackling, interception, dan marking (Asepta Y.P., 2008: 16-17). Karena sampel atau subyek penelitiannya siswa putra usia 12-14 tahun maka yang akan diteliti adalah teknik dasar yang memegang peranan yang penting dalam permainan sepak bola yaitu teknik shooting/menendang bola. Shooting adalah teknik yang harus benar-benar dikuasai oleh siswa dalam permainan sepak bola tingkat pemula, karena untuk dapat menyerang regu lawan dan akhimya diharapkan dapat memenangkan suatu pertandingan sepak bola, para siswa atau atlet harus mempergunakan teknik menendang bola ke gawang lawan dan teknik ini juga berperan penting jika mendapat hadiah pinalti atau terjadi adu pinalti karena terjadi sekor imbang pada batas waktu yang telah ditetapkan.

Menurut Suharno HP (1995:20) unsur-unsur kondisi fisik yang mendukung kemampuan teknik keterampilan olahraga adalah: kekuatan, daya tahan, kecepatan, kelentukan, kelentukan, daya ledak, koordinasi, ketepatan, dan stamina, Sedang menurut Sugiyanto (1994:4) mengutip pendapat Anita J. Harrow 
yang membagi 6 klasifikasi gerakan tubuh yaitu: gerak refleks, gerak dasar manusia, kemampuan perseptual, kemampuan fisik, gerak keterampilan, dan komunikasi non diskursif.

Dalam hal ini peneliti akan memfokuskan penelitian pada unsur kondisi fisik yaitu unsur kekuatan, dan kelentukan serta klasifikasi gerakan tubuh kemampuan persepsual yang masih dibagi menjadi lima macam yaitu: pembedaan rasa gerak (kinestetik), pembedaan penglihat (visual), pembedaan pendengar (auditori), pembedaan peraba (taktil), dan kemampuan koordinasi. Peneliti mengambil kemampuan koordinasi untuk melengkapi kemampuan kondisi fisik di atas.

Berdasarkan pengamatan peneliti, teknik keterampilan shooting dapat dilakukan dengan baik, apabila para pemain mempunyai bekal kekuatan otot tungkai yang baik. Oleh karena di dalam melakukan teknik shotting dalam permainan sepak bola, pemain harus menendang bola ke sasaran dengan kuat, agar dalam beraksi tersebut dapat berhasil dengan baik maka para pemain yang mau melakukan teknik tersebut harus menggunakan anggota tubuhnya dengan kelentukan yang baik terutama untuk melakukan gerak tipu. Dalam pelaksanaan tersebut, para pemain juga harus memperhatikan keras lunaknya bola, tebal tipisnya rumput, sehingga membantu pemain dalam menentukan putusan arah shooting, dalam hal ini pembedaan rasa gerak atau persepsi kinestetik dituntut lebih dominan.

Dengan mendasarkan pada paparan di atas, maka penelitian ini akan dan lebih difokuskan pada keterkaitan atau hubungan antara kekuatan otot tungkai, kelentukan dan persepsi kinestetik dengan teknik keterampilan menembak bola ke gawang atau shooting.

\section{B. METODE PENELITIAN}

Tujuan dalam penelitian ini adalah untuk mengetahui ada tidaknya hubungan antara dua atau beberapa variabel. Menurut Suharsimi Arikunto 
(2000:326), penelitian korelasional adalah pilihan yang sesuai untuk mencapai tujuan tersebut.Dalam penelitian ini variabel bebas disebut juga sebagai prediktor dan variabel terikat yang disebut juga sebagai kriterium. Hal ini sesuai dengan pendapat R.G. Sudarmanto (2005:2) yang menyatakan bahwa untuk penggunaan analisis regresi variabel bebas sebagai prediktor dan variabel terikat sebagai kriterium.

\section{HASIL PENELITIAN}

\section{A. Deskripsi Data}

Data yang diperoleh dalam penelitian ini merupakan hasil dari tes dan pengukuran power otot tungkai, kelentukan, dan persepsi kinestetik dengan ketepatan shooting sepakbola pada pemain usia 12-14 tahun SSB Matra Kebakkramat, Karanganyar Tahun 2020, yang dideskripsikan sebagai berikut:

Tabel 1. Deskripsi data hasil tes dan pengukuran power otot tungkai (X1), kelentukan (X2), persepsi kinestetik (X3), dan ketepatan shooting (Y)

\begin{tabular}{|c|l|c|c|c|c|c|}
\hline \multirow{2}{*}{ No. } & \multirow{2}{*}{ Variabel } & \multirow{2}{*}{$\mathrm{N}$} & \multicolumn{2}{|c|}{ Mean } & \multicolumn{2}{c|}{ SD } \\
\cline { 4 - 7 } & & & Tes & Retes & Tes & Retes \\
\hline 1. & Power Otot Tungkai (X1) & 30 & 1,683 & 1,728 & 0,201 & 0,211 \\
\hline 2. & Kelentukan (X2) & 30 & 10,493 & 11,147 & 3,827 & 3,803 \\
\hline 3. & Persepsi Kinestetik (X3) & 30 & 3,333 & 2,733 & 1,028 & 0,944 \\
\hline 4. & Ketepatan Shooting (Y) & 30 & 12,833 & 15,00 & 4,857 & 4,549 \\
\hline
\end{tabular}

Dari tabel di atas dapat diketahui rata-rata tes power otot tungkai sebesar 1,683, simpangan baku sebesar 0,201, rata-rata tes kelentukan sebesar 10,493, simpangan baku 3,827, rata-rata tes persepsi kinestetik sebesar 3,333, simpangan baku sebesar 1,028, dan rata-rata tes ketepatan shooting sepakbola sebear 12,833, simpangan baku sebesar 4,857. Sedangkan untuk rata-rata retes power otot tungkai sebesar 1,728, simpangan baku sebesar 0,210, rata-rata retes kelentukan sebesar 11,147, simpangan baku sebesar 3,803, rata-rata retes persepsi kinestetik sebesar 2,733, simpangan baku sebesar 0,944 dan rata-rata retes ketepatan shooting sepakbola sebesar 15,00, simpangan baku sebesar 4,549. 
Untuk mengetahui keajegan alat ukur atau tes yang dipergunakan dalam penelitian ini, akan dan bahkan sangat perlu dilakukan uji reliabilitas tes dengan menggunakan metode tertentu yang disebut metode tes retes.

Adapun hasil dari uji reliabilitas tes tersebut, kemudian akan dikemukakan dalam Tabel 2, dan mengenai hasil dari koefisien reliabilitas yang telah diketahui akan dikonsultasikan dengan Range Kategori dari Book Walter seperti tertera dalam Tabel 3 di bawahnya.

Tabel 2. Koefisien reliabilitas tes Power Otot Tungkai (X1), Kelentukan (X2), Persepsi Kinestetik (X3), dan Ketepatan Shooting (Y)

\begin{tabular}{|c|c|c|c|c|c|c|c|}
\hline \multirow{2}{*}{ No } & \multirow{2}{*}{ Variabel } & \multirow{2}{*}{$\mathrm{N}$} & \multicolumn{2}{|c|}{ Mean } & \multicolumn{2}{|c|}{ SD } & \multirow{2}{*}{$\mathrm{R}$} \\
\hline & & & Tes & Retes & tes & retes & \\
\hline 1. & Power otot tungkai (X1) & 30 & 1,683 & 1,728 & 0,201 & 0,211 & $0, .987$ \\
\hline 2. & Kelentukan (X2) & 30 & 10,493 & 11,147 & 3,827 & 3,803 & 0,956 \\
\hline 3. & Persepsi Kinestetik (X3) & 30 & 3,333 & 2,733 & 1,028 & 0,944 & 0,521 \\
\hline 4. & Ketepatan Shooting (Y) & 30 & 12,833 & 15,00 & 4,857 & 4,549 & 0,819 \\
\hline
\end{tabular}

Tabel 3. Range Kategori Book Walter

\begin{tabular}{|c|c|}
\hline Kategori & Reliabilitas \\
\hline Tinggi Sekali & $0,90-1,00$ \\
\hline Tinggi & $0,80-0,89$ \\
\hline Cukup & $0,60-0,79$ \\
\hline Kurang & $0,40-0,59$ \\
\hline Tidak Signifikan & $0,00-0,39$ \\
\hline
\end{tabular}

Berdasarkan Range Kategori dari Book Walter yang tertera di atas, maka koefisien reliabilitas tes power otot tungkai sebesar 0,98 masuk kategori tinggi sekali, koefisien reliabilitas tes kelentukan sebesar 0,956 masuk kategori tinggi sekali, koefisien reliabilitas tes persepsi kinestetik sebesar 0,521 masuk kategori kurang, dan koefisien reliabilitas tes ketepatan shooting sepakbola sebesar 0,819 masuk kategori tinggi.

Sehingga dapat disimpulkan bahwa tes-tes yang digunakan untuk mengumpulkan data dalam penelitian ini, terpercaya keajegannya sehingga data 
yang terkumpul atau diperolek dari tes-tes yang telah dipergunakan tersebut dapat diolah atau dianalisis untuk keperluan pembuktian hipotesis penelitian yang telah dirumuskan oleh peneliti pada bab sebelumnya.

\section{A. Uji Prasyarat Analisis}

\section{a. Uji Normalitas}

Hasil dari uji normalitas diperlihatkan pada Tabel 4 di bawah:

Tabel 4. Hasil uji normalitas data tes Power Otot Tungkai (X1), Kelentukan (X2), Persepsi Kinestetik (X3), dan Ketepatan Shooting (Y)

\begin{tabular}{|c|l|c|c|c|c|c|}
\hline No & \multicolumn{1}{|c|}{ Variabel } & N & Mean & SD & $\begin{array}{c}\text { Asym } \\
\text { p.Sig. }\end{array}$ & $\begin{array}{c}\text { Alpha } \\
5 \%\end{array}$ \\
\cline { 1 - 5 } 1. & Power otot tungkai (X1) & 30 & 1.68 & 0.20 & 0.665 & \\
\cline { 1 - 5 } 2. & Kelentukan (X2) & 30 & 9.90 & 0.54 & 0.116 & \\
\cline { 1 - 5 } 3. & Koorninasi Mata Kaki (X3) & 30 & 14.03 & 1.79 & 0.094 & \multirow{2}{*}{0.05} \\
\hline 4 & Ketepatan Shooting (Y) & 30 & 12.83 & 4.85 & 0.074 & \\
\hline
\end{tabular}

Berdasarkan nilai Asymp. Sig. (2-tailed) yang diperoleh setelah dibandingkan dengan alpha 0.05, ternyata nilai Asymp. Sig.(2-tailed) lebih besar (>) dari alpha 0.05. Sehingga dapat disimpulkan data power otot tungkai, kelentukan, persepsi kinestetik dan ketepatan shooting sepakbola masuk dalam kategori distribusi normal.

\section{b. Uji Linieritas}

Uji linieritas antara masing-masing prediktor yaitu power otot tungkai (X1), kelentukan (X2), persepsi kinestetik (X3), dengan kriterium yaitu ketepatan shooting sepakbola dilakukan dengan analisis tabel Anova. Adapun rangkuman hasil uji linieritas tersebut dapat dilihat dalam Tabel 5 sebagai berikut:

Tabel 5. Rangkuman hasil uji linieritas

\begin{tabular}{|c|c|c|c|c|}
\hline Variabel & Signifikansi & Alpha & Kondisi & Simpulan \\
\hline $\mathrm{X}_{1} \mathrm{Y}$ & 0,394 & 0,05 & $\mathrm{~S}>\mathrm{A}$ & Linier \\
\hline $\mathrm{X}_{2} \mathrm{Y}$ & 0,826 & 0,05 & $\mathrm{~S}>\mathrm{A}$ & Linier \\
\hline
\end{tabular}




\begin{tabular}{|l|l|l|l|l|}
\hline $\mathrm{X}_{3} \mathrm{Y}$ & 0,426 & 0,05 & $\mathrm{~S}>\mathrm{A}$ & Linier \\
\hline
\end{tabular}

Dari rangkuman hasil uji linieritas, dapat disimpulkan bahwa semua data yang terkumpul berbentuk linier, oleh karena hasil perhitungan Deviation from Linearity dari tabel Anova > dari harga Alpha 5\% yang ditetapkan.

\section{B. Hasil Analisis Data}

\section{Korelasi masing-masing variabel bebasdengan variabel terikat}

Hasil analisis data penelitian dapat dilihat dalam Tabel 6 berikut:

\begin{tabular}{|c|c|c|c|c|}
\hline $\mathrm{X}-\mathrm{Y}$ & $\mathrm{N}$ & $\mathrm{r}_{\mathrm{xy}}$ & $\mathrm{r}_{\text {tabel } 5 \%}$ & Keterangan \\
\hline $\mathrm{X} 1-\mathrm{Y}$ & 30 & 0,458 & 0,361 & Signifikan \\
\hline $\mathrm{X} 2-\mathrm{Y}$ & 30 & 0,582 & 0,361 & Signifikan \\
\hline $\mathrm{X} 3-\mathrm{Y}$ & 30 & 0,450 & 0,361 & Signifikan \\
\hline
\end{tabular}

Berdasarkan hasil analisis data dalam Tabel 6 tersebut di atas, diketahui hasil koefisien korelasi antara power otot tungkai dengan ketepatan shooting sepakbola sebesar 0,458, koefisien korelasi antara kelentukan dengan ketepatan shooting sepakbola sebesar 0,582, dan koefisien korelasi antara persepsi kinestetik dengan ketepatan shooting sepakbola sebesar 0,450. Sedangkan angka batas penolakannya pada taraf signifikansi 5\% sebesar 0,361 , sehingga semua variabel bebas ada hubungannya dengan variabel terikat.

\section{Analisis regresi tiga prediktor}

Untuk mengetahui korelasi antara 3 prediktor dengan 1 kriterium dengan menggunakan analisis regresi. Adapun persamaan garis regresinya berdasarkan analisis data adalah sebagai berikut :

$$
\mathrm{Y}=-3,975 \mathrm{X} 1+0,355 \mathrm{X} 2+1,071 \mathrm{X} 3+12,234
$$

Hasil dari analisis regresi data penelitian dapat dilihat dari rangkuman Tabel 7 berikut:

\begin{tabular}{|c|c|c|c|c|c|}
\hline Sumber Variasi & SS & Db & MS & F & $\mathrm{R}_{(1,2,3)}$ \\
\hline Regresi & 94,821 & 3 & 31,607 & 3,394 & 0,267 \\
\hline Residu & 589,346 & 26 & 22,667 & & \\
\hline
\end{tabular}




\begin{tabular}{|l|c|c|c|c|c|}
\hline Total & 684,167 & 29 & & & \\
\hline
\end{tabular}

\section{Pembahasan Hasil Analisis Data}

\section{Korelasi variabel bebas $(\mathrm{X})$ dengan variabel terikat $(\mathrm{Y})$}

a. Korelasi variabel bebas $\left(\mathrm{X}_{1}\right)$ dengan variabel terikat $(\mathrm{Y})$

Dalam hasil analisis data pada Tabel 6 diketahui bahwa koefisien korelasi $\left(\mathrm{r}_{\mathrm{xly}}\right)$ sebesar 0,458 ternyata lebih besar dengan harga $\mathrm{r}$ tabel 5\%= 0,361, sehingga dapat disimpulkan bahwa hipotesis diterima berarti ada hubungan antara power otot tungkai dengan ketepatan shooting sepakbola.

b. Korelasi variabel bebas $\left(\mathrm{X}_{2}\right)$ dengan variabel terikat $(\mathrm{Y})$

Dalam hasil analisis data pada Tabel 6 diketahui bahwa koefisien korelasi $\left(\mathrm{r}_{\mathrm{xly}}\right)$ sebesar 0,582 ternyata lebih besar dengan harga $\mathrm{r}$ tabel 5\%= 0,361, sehingga dapat disimpulkan bahwa hipotesis diterima berarti ada hubungan antara kelentukan dengan ketepatan shooting sepakbola.

c. Korelasi variabel bebas $\left(\mathrm{X}_{3}\right)$ dengan variabel terikat $(\mathrm{Y})$

Dalam hasil analisis data pada Tabel 6 diketahui bahwa koefisien korelasi $\left(\mathrm{r}_{\mathrm{xly}}\right)$ sebesar 0,450 ternyata lebih besar dengan harga $\mathrm{r}$ tabel $5 \%=$ 0,361, sehingga dapat disimpulkan bahwa hipotesis diterima berarti ada hubungan antara persepsi kinestetik dengan ketepatan shooting sepakbola.

\section{Analisis Regresi Tiga Prediktor}

Berdasarkan hasil analisis data dalam Tabel 7, diketahui hasil analisis regresi tiga prediktor $(\operatorname{Ry}(123))$ sebesar 0,372 dan F hitung sebesar 3,394. Sedangkan harga $\mathrm{r}$ tabel pada taraf signifikansi 5\% sebesar 0,372 dan harga F tabel 5\% (3:26) sebesar 2,89. Dengan demikian harga $\mathrm{R}$ hitung $>$ harga $\mathrm{r}$ tabel dan harga $\mathrm{F}$ hitung $>$ harga F tabel, sehingga dapat disimpulkan bahwa ketiga prediktor yaitu power otot tungkai, persepsi kinestetik, dan kelentukan mempunyai hubungan yang meyakinkan dengan kriteriumnya, yaitu ketrampilan shooting sepakbola. 


\section{SIMPULAN}

Berdasarkan analisis data dan pengujian hipotesis yang telah dilakukan, maka simpulan yang dapat diperoleh adalah sebagai berikut :

1. Ada hubungan yang positif dan signifikan antara power otot tungkai dengan ketepatan shooting sepak bola pada pemain usia 12-14 tahun SSB Matra Kebakkramat, Karanganyar Tahun 2020, dengan $r_{x y}=0,458>$ r t5\% $=0,361$.

2. Ada hubungan yang positif dan signifikan antara kelentukan dengan ketepatan shooting sepak bola pada pemain usia 12-14 tahun SSB Matra Kebakkramat, Karanganyar Tahun 2020, dengan $r_{x y}=0,582>r$ t5 $\%=0,361$.

3. Ada hubungan yang positif dan signifikan antara persepsi kinestetik dengan ketepatan shooting sepak bola pada pemain usia 12-14 tahun SSB Matra Kebakkramat, Karanganyar Tahun 2020, dengan $r_{x y}=0,450>$ r t5\% $=0,361$. Ada hubungan yang positif dan signifikan antara power otot tungkai, kelentukan, dan persepsi kinestetik dengan ketepatan shooting sepak bola pada pemain usia 12-14 tahun SSB Matra Kebakkramat, Karanganyar Tahun 2020, dengan $R_{y(1,2,3)}=$ $0,372>\mathrm{r} \mathrm{t} 5 \%=0,361$ dan $\mathrm{F}$ hitung $=3,394>\mathrm{F} \mathrm{t} 5 \%=2,89$

\section{DAFTAR PUSTAKA}

Asepta Y.P. 2008. Sepak Bola: Sejarah, Teknik, Perawan. Surabaya: Intan Cendekia.

Fleck, T. dan Quinn, R. 2008. Panduan Latihan Sepak Bola Andal. Jakarta: I'T SimdaKelapa Pustaka.

Harsono. 1988. Coaching dan Aspek-aspek Psikologis dalam Coaching. Jakarta: CV Tambak Kusumu.

Ismaryati. 2007. Tes dan Pengukuran Olahraga. Surakarta: Sebelas Maret University Press.

Johnson, B.L. and Nelson, J.K. 1986. Practical Measurements for Evolution in Physical Education. New York : Macmillan Publishing Company.

M. Yunus. 1991/1992. Olahraga Pilihan Bola Voli. Jakarta: Dirjen Dikti.

M. Yusuf, H., dan Aip, S. 1996. Ilmu Kepelatihan Dasar, Jakarta: Dirjen Dikti. 